\title{
Life Cycle of the Chitose Tornado of September 22, 1988
}

\author{
By Fumiaki Kobayashi ${ }^{1}$, Katsuhiro Kikuchi and Hiroshi Uyeda \\ Department of Geophysics, Faculty of Science, Hokkaido University, Sapporo 060, Japan
}

(Manuscript received 22 September 1994, in revised form 25 December 1995)

\begin{abstract}
In the afternoon of September 22, 1988, a supercell storm developed over the Ishikari Plain, in Hokkaido, Japan. A single-funnel F1 tornado was spawned in Chitose City, near Sapporo. The characteristics of the structure and the life cycle of the Chitose tornado were revealed by radar observations, ground survey, photographs, videotape, and meteorological data analyses. The Chitose tornado had a lifetime of 20 minutes and funnel width of $150 \mathrm{~m}$ at cloud base. The life cycle of the tornado was divided into four stages according to the detailed structure of the funnel and damage characteristics: the formation stage was characterized by a descending funnel, the mature stage characterized by touchdown of a visible funnel and a formation of strong dust cloud, the shrinking stage characterized by tilting and meandering funnel, and decaying stage that lead to the dissipation of the funnel.

The mesocyclone of $7 \mathrm{~km}$ in diameter developed at $2.5 \mathrm{~km}$ AGL in the parent cloud and was accompanied by a misocyclone of $1 \mathrm{~km}$ in diameter. The angular momentum of the tornado circulation at the height of $400 \mathrm{~m}$ AGL was nearly equal to that of the misocyclone at $2.5 \mathrm{~km}$ AGL. The time and space relationship between surface damage, the tornado funnel and the mesocyclone was revealed. The width of the surface damage area was nearly equal to the width of the dust cloud $(200 \mathrm{~m})$ and was 10 times larger than the surface funnel width. Although the surface funnel initially formed right below the misocyclone, the funnel top near the cloud base and the funnel bottom near the surface moved in quite different ways, since the parent cloud moved at a speed of $5 \mathrm{~ms}^{-1}$ and the surface funnel at a speed of $1.2 \mathrm{~ms}^{-1}$.
\end{abstract}

\section{Introduction}

Tornadoes are called 'tatsumaki' in Japanese, the meaning of which includes landspouts, waterspouts and tornadoes. While many meteorologists have been interested in tornadoes and lots of case studies of tornadic disasters have been reported, the detailed structures of tornadoes or waterspouts are not well known in Japan. Recently, an increasing number of images taken by amateur cameramen are becoming available when special natural disaster events occur because personal video-cameras are now popular. These image data are very important to the understanding local severe weather events, such as tornadoes, microbursts, local fronts, and so on.

Recently, a detailed structural relationship between a hook echo, misocyclone and a tornado funnel was observed using a high-resolution Doppler radar and cloud photogrammetry during the CINDE (Convective Initiation and Downburst Experiment) project in the United States (Wakimoto and Martner, 1992). On the other hand, single-Doppler

1 Present affiliation: Department of Geoscience, National Defense Academy, Yokosuka 239, Japan

(C)1996, Meteorological Society of Japan radar observations of tornadic storms have been carried out in Japan lately. Niino et al. (1993) reported a single-Doppler radar analysis of a mesocyclone associated with the Chiba tornado on December 11, 1990. However, until now in Japan, no papers have reported on the life cycle of a tornado, such as a temporal change of a visible funnel cloud accompanied with the surface damaged data and Doppler radar data.

In the afternoon of September 22, 1988, severe thunderstorms occurred over the Ishikari Plain, Hokkaido, Japan. Hailstones with a maximal diameter of $3 \mathrm{~cm}$ were observed in the suburbs of Sapporo. At around $1310 \mathrm{JST}$, a tornado occurred at a distance of $35 \mathrm{~km}$, southeast of Sapporo, near the Chitose Airport. These events were observed by a single Doppler radar (Kikuchi et al., 1990, Shirooka and Uyeda, 1991). Moreover, our chasing team examined characteristics of the surface damage area and collected photographs and a videotape of the tornado. The Chitose tornado was the first tornado in Japan for which the entire life cycle of the funnel and the parent cloud were photographed and videotaped together with the surface damage and Doppler radar data. 


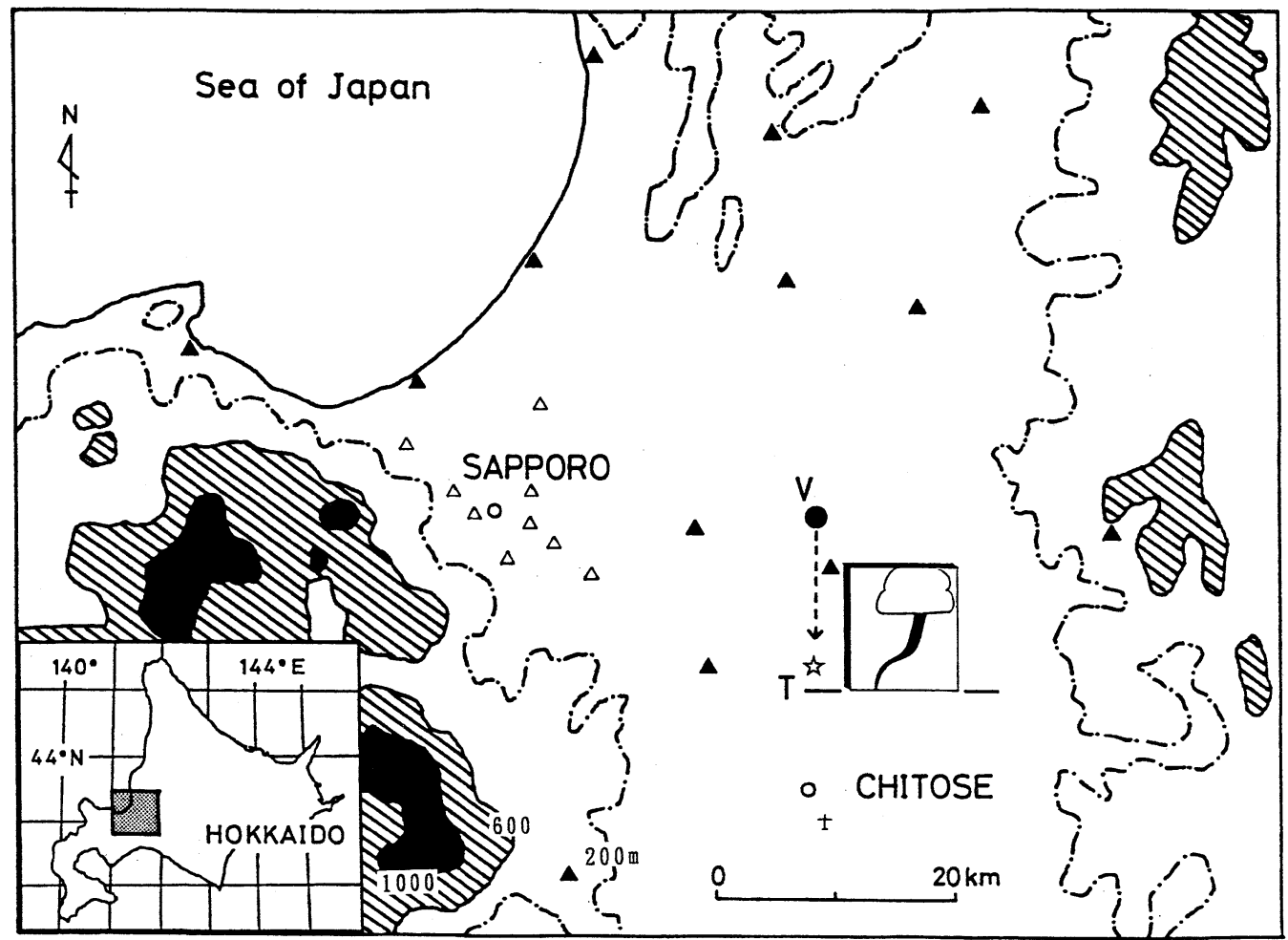

Fig. 1. The topography around the Ishikari Plain, Hokkaido. A star mark (T) and a solid circle (V) denote the locations of the tornado and the videophotographing, respectively. Solid triangles and open triangles show AMeDAS stations and weather stations of Sapporo City, respectively.

In this paper, we will analyze the characteristic features of the Chitose tornado at various stages of its life cycle by using successive data from radars, photographs, a videotape, ground survey, soundings and surface meteorological observations. The purpose of this paper is 1) to describe the detailed structure of a tornado funnel and 2) to compare the life cycle of the tornado funnel with that of its parent cloud.

\section{Characteristics of the Chitose tornado at various stages}

Figure 1 shows a map of the topography around the Ishikari Plain, Hokkaido. The tornado touched down $10 \mathrm{~km}$ north of Chitose Airport. A number of photographs and a videotape were taken from five different points which were within a radius of $20 \mathrm{~km}$. In this study, photographs taken very close to the tornado (several tens of meters), and a videotape taken from $12 \mathrm{~km}$ to the north (point V in Fig. 1) were used to analyze the evolution of the tornado funnel.

Little distinct damage were caused by the tornado because it merely passed over a radish field, waste field and several woods. However, the whole movement of the funnel and the details of the damage were revealed by the ground survey and several eyewitnesses. The overall damage features are indicated in Fig. 2. The tornado path from Point 2 to Point 4 in the figure was determined from ground marks caused by the tornado. The outer edge of the surface damage area (shaded area in the figure) was characterized by scattered debris. The F-scale typically ranged from F0 to F1: At Points 1 and 2, trees were snapped and uprooted (F1). At Point 4, F0 damage to the radish field was found and at Point 5 , a moving truck was partly damaged (F0).

The FPP-scale intensity (defined by Fujita(1973)) of the Chitose tornado was $(\mathrm{F}, \mathrm{P}, \mathrm{P})=(1,0,1)$ : the surface damage length was $1.5 \mathrm{~km}$ and the damage width was $50 \mathrm{~m}$. The life time of the tornado was approximately 20 minutes. Its life cycle may be divided into four stages according to the changes in the damage characteristics and the appearance of the tornado funnel: formation, mature, shrinking and decaying stages (e.g., Golden and Purcell, 1978). The tornado characteristics in each stage will be described in detail in the following.

\subsection{Formation stage}

The first stage of the life cycle of the Chitose tornado lasted from 1308 to 1312 JST during which the funnel cloud remained aloft. The Chitose tornado started its life at around 1308 JST according to eyewitnesses who observed the tornado vortex at a cloud base from just below. The condensation funnel formed at the cloud base a few minutes be- 


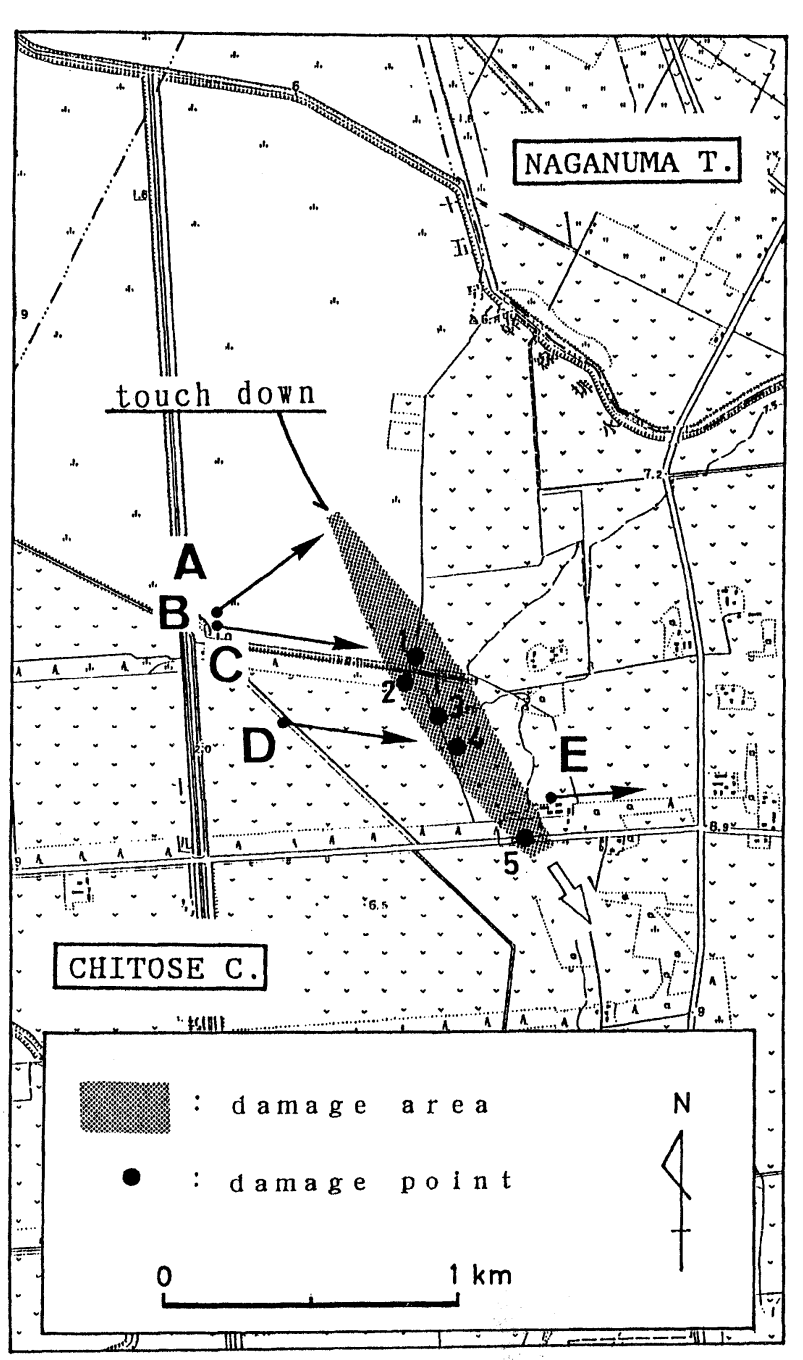

Fig. 2. Damage map of the Chitose tornado. Letters A-E indicate points where the corresponding pictures in Fig. 3 were taken. Numbers 1-5 denote points where distinct damage were observed.

fore the surface "dust column", which is defined as a part of the tornado vortex visualized by dust. Figures $3 \mathrm{~A}$ and $3 \mathrm{~B}$ are successive photographs of the tornado funnel taken about thirty seconds apart, just after the touchdown of the tornado vortex. The parent vortex of the funnel cloud at the cloud base began to increase its vorticity after a few seconds and spawned the tornado funnel visible in the photographs (about 1310 JST). When the lower end of the funnel cloud had sharpened and descended about two-thirds of the way to the ground, the dust column had already formed below the funnel, as shown in Figs. 3A and 3B.

Figure 4 shows video images at four different stages. At the time of formation, the funnel width was $150 \mathrm{~m}$ wide at the cloud base and $75 \mathrm{~m}$ at half way (600 m AGL, Fig. 4a). The funnel cloud extended to the ground from the parent cloud, the cloud base of which was about $1200 \mathrm{~m}$ AGL.

\subsection{Mature stage}

The second stage of the tornado life cycle is characterized by the contact of the funnel cloud with the ground and an intense "dust cloud", which is defined as a visible white dust formed around the funnel. It lasted from about 1312 to 1318 JST. The funnel cloud reached the ground at 1312 and remained in contact with the ground. The dust cloud around the funnel grew in size and became ten times larger in diameter than the surface funnel (Fig. 3C, 4b). While the width of the damage path reached $200 \mathrm{~m}$, the width of severely damaged area $(>\mathrm{F} 0)$ was about $50 \mathrm{~m}$.

During this stage, a strong rotation associated with the parent vortex of the funnel cloud was apparent at the cloud base. Figure 5 is one of the photographs of the funnel and the parent cloud taken almost from just below looking eastward. The funnel cloud spiralled into the parent vortex at the cloud base, the diameter of which was about ten times as wide (about $1 \mathrm{~km}$ ) as that of the funnel at the cloud base. The tornado vortex at the cloud base was located at the eastern edge of the parent cloud (clear sky is seen in the figure).

When the funnel cloud made a contact with the ground, the funnel width was $60 \mathrm{~m}$ at the cloud base and $30 \mathrm{~m}$ at half way. The surface tornado vortex width determined from surface tornadic traces, as shown in Fig. 6, was about $20 \mathrm{~m}$ in diameter. A strong dust cloud developed up to one-third of the way to the cloud base from the ground. Its diameter reached $200 \mathrm{~m}$ near the surface. The width of the damage path increased and reached $200 \mathrm{~m}$, comparable to the diameter of the dust cloud, during this stage. The difference of the width between the dust cloud and the damage may be caused by a change in the ground surface condition.

The wind speed of the Chitose tornado in the mature stage was not estimated from any damage to structures, as there was no construction in the vicinity of the tornado. However, flying debris separate from the dust cloud was found in the continuous video images (Kobayashi and Kikuchi, 1994). Figure 7 shows a trajectory of the flying object for one-second intervals. Tangential and vertical components of the airflow around the tornado were calculated from each vector of the object by the image-analysis method using two-dimensional video frames. The calculation showed that the maximum tangential and vertical wind speeds of the tornado were $70 \pm 12 \mathrm{~ms}^{-1}$ and $85 \pm 10 \mathrm{~ms}^{-1}$, respectively, at a height of $400 \mathrm{~m} \mathrm{AGL} \mathrm{(Fig.} \mathrm{8).}$

\subsection{Shrinking stage}

After the tornado had moved over the wood as shown in the right side of Fig. 3C, the funnel cloud began to twist and meander gradually (Fig. 3D, 4c). 

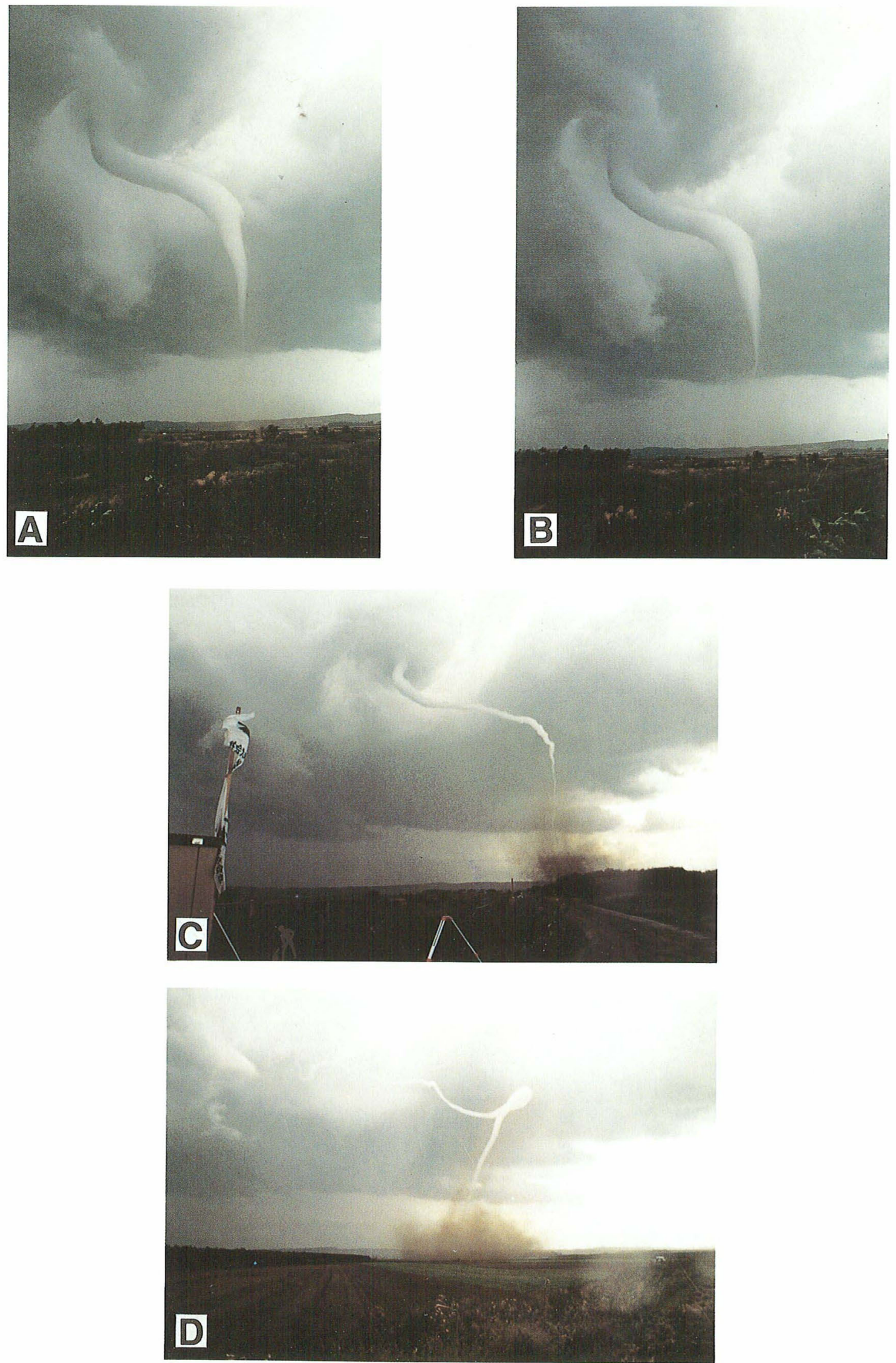

Fig. 3. Successive photographs of the tornado through its life cycle. Letters correspond to the locations in Fig. 2. A, B: formation stage. C: mature stage. D: shrinking stage. E: decaying stage. 


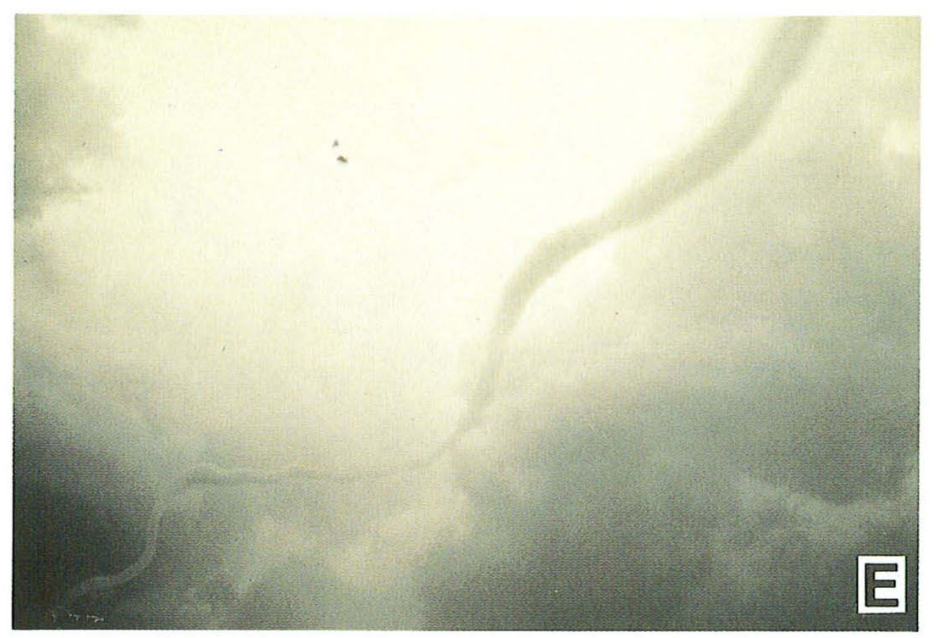

Fig. 3. (Continued)

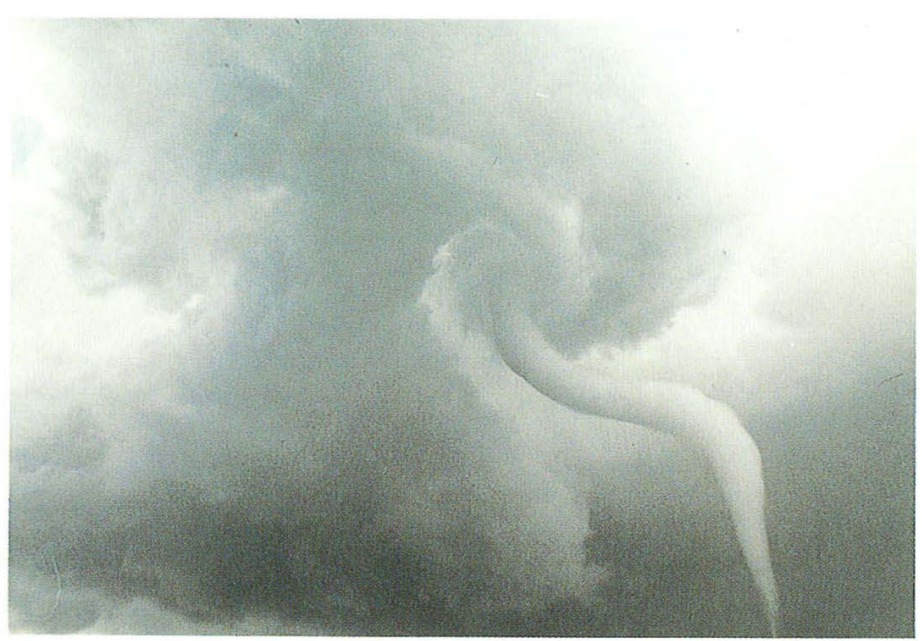

Fig. 5. The funnel cloud and the parent cloud at a cloud base in the mature stage, taken just below the tornado. Looking toward the east.

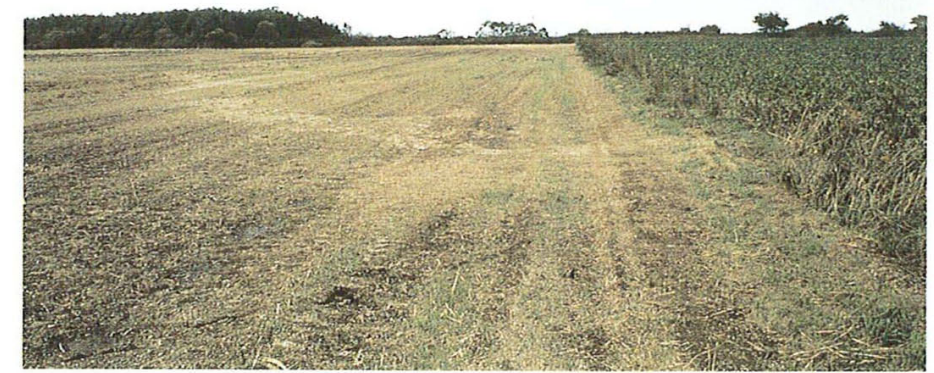

Fig. 6. The tornadic trace on the ground surface (Point 3 in Fig. 2). Looking toward the north. 


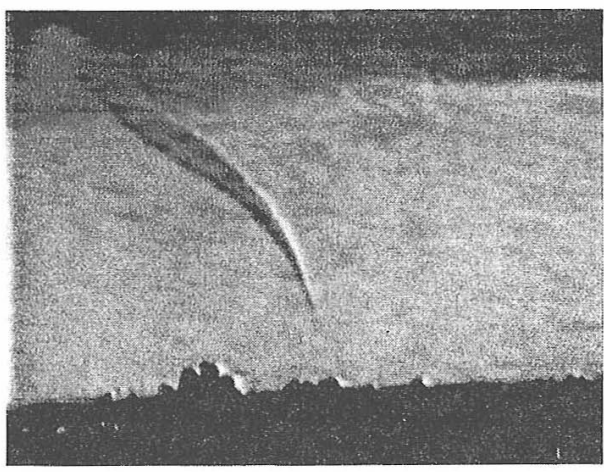

(a)

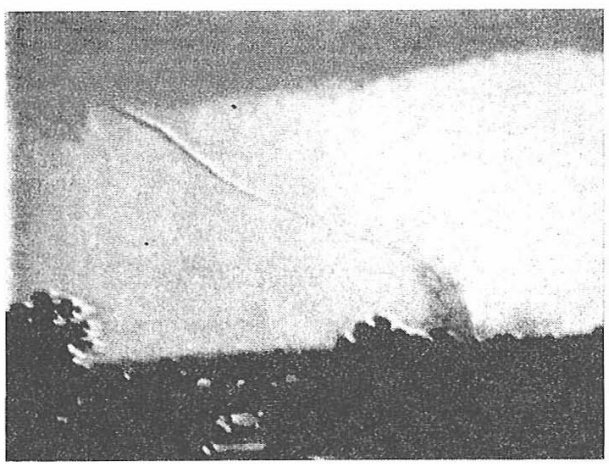

(c)

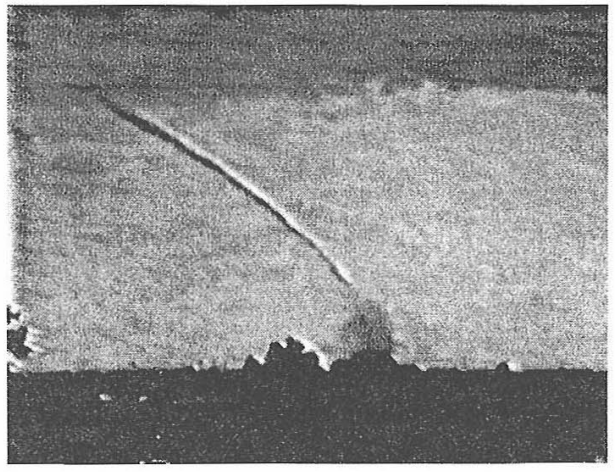

(b)

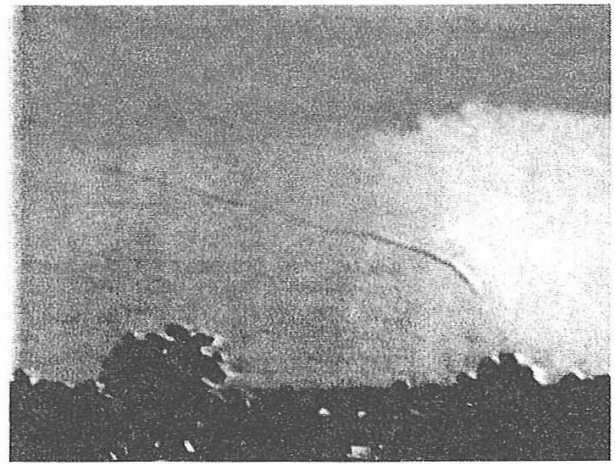

(d)

Fig. 4. Successive video frames of the tornado funnel. The video was taken looking south (see Fig. 1). (a) Formation stage. (b) Mature stage. (c) Shrinking stage. (d) Decaying stage.

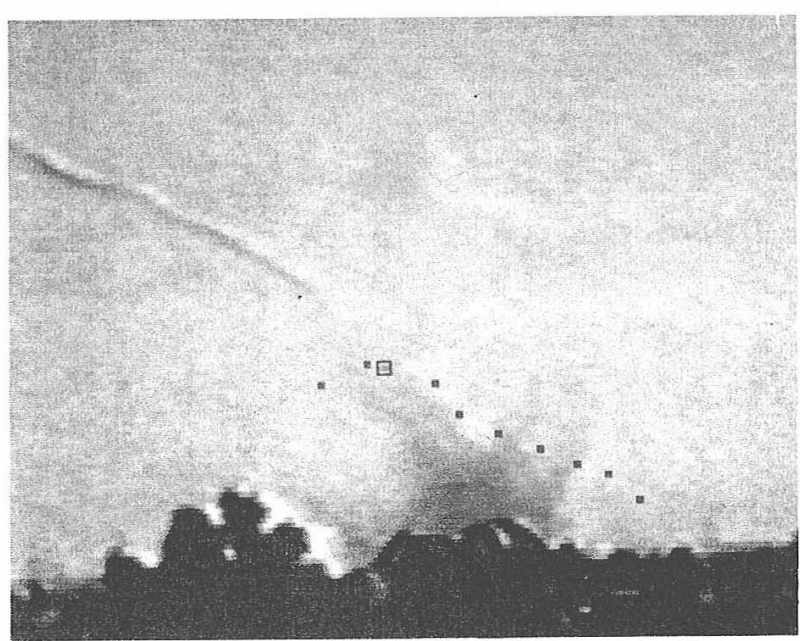

Fig. 7. Image analysis of the flying debris. Each dot shows the position of the object taken at one-second intervals.

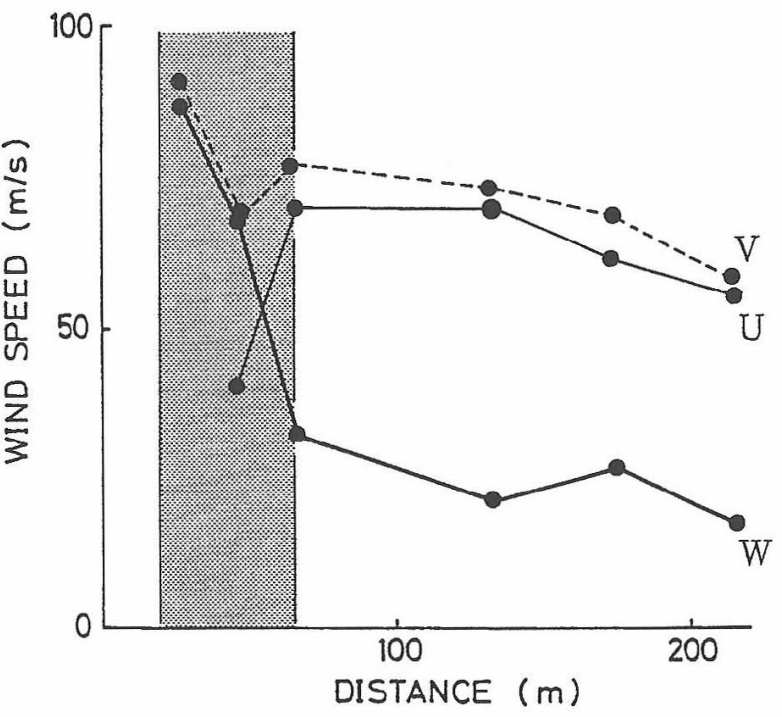

Fig. 8. Space distributions of a horizontal windspeed (U), updraft (W) and total wind(V) calculated from the object shown in Fig. 7. Shaded area shows the averaged region of the dust cloud. (after Kobayashi and Kikuchi, 1994). 


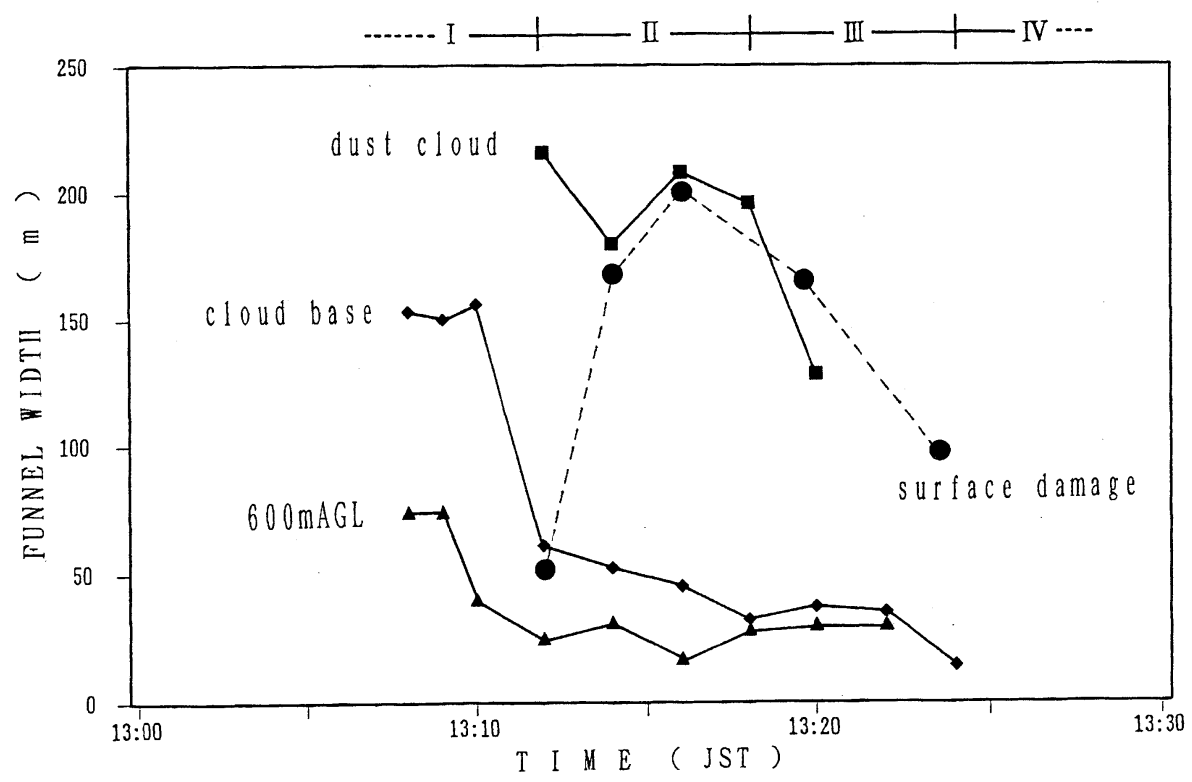

Fig. 9. The funnel width at three different levels, the cloud base (1200 m above ground level (AGL)), half way ( $600 \mathrm{~m} \mathrm{AGL)}$ and near surface (100 m AGL, the dust cloud width). The dashed line denotes the width of surface damage area. Roman numerals I, II, III and IV denote the evolution stage of the tornado.

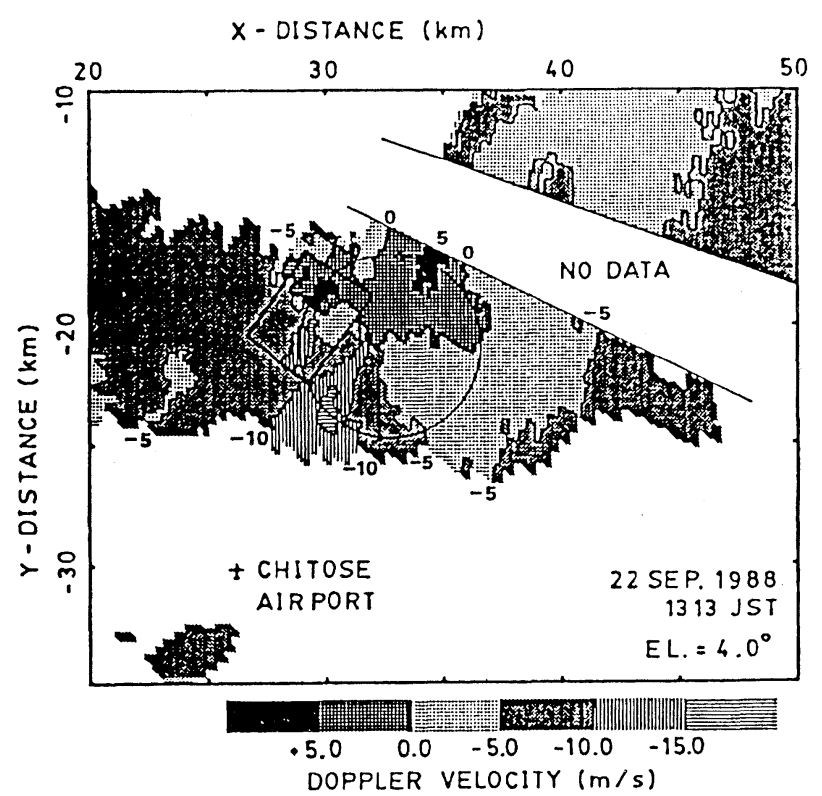

Fig. 10. PPI display of the Doppler velocity at 1313 JST. X and Y distances are from the Doppler radar site. (after Kikuchi et al., 1990).

While the funnel tilted strongly to the southeast direction, it maintained a continuous vortex tube visualized by the rope-shaped funnel cloud. Moreover, the funnel was almost vertical near the surface, as shown in Fig. 3D. The tornado still had its destructive power near the ground at this stage. The dust cloud was apparent near the surface and distinct damage was produced during this stage.

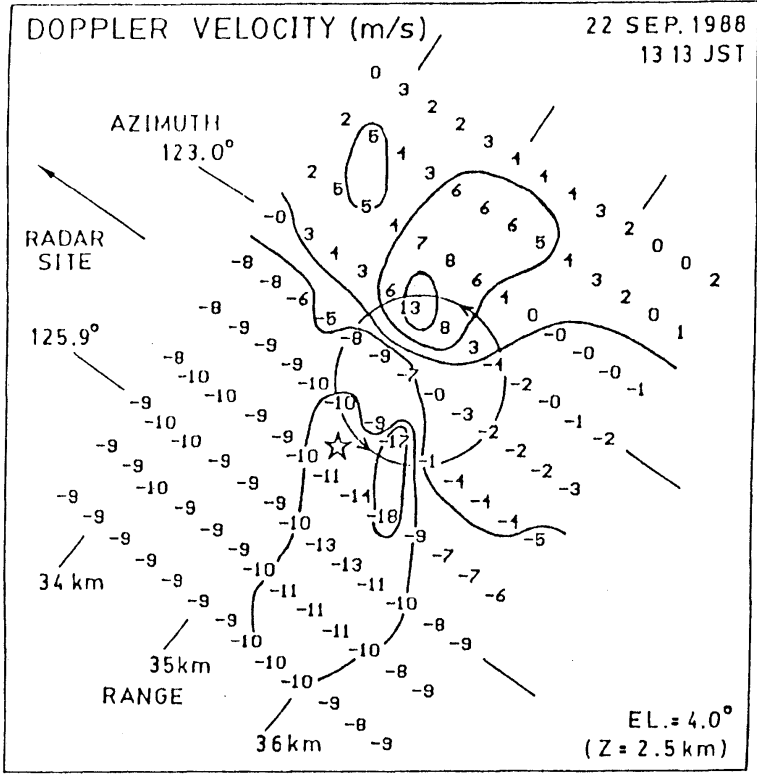

Fig. 11. Contours of the Doppler velocity $\left(\mathrm{ms}^{-1}\right)$ in the rectangular area of Fig. 10. The star mark denotes the location of the tornado on the ground. (after Kikuchi et al., 1990).

Whereas the width of the funnel cloud remained $35 \mathrm{~m}$ in diameter at the cloud base and $30 \mathrm{~m}$ at half way, that of the dust cloud near the ground rapidly narrowed from $200 \mathrm{~m}$ to $120 \mathrm{~m}$ at $1320 \mathrm{JST}$. The width of the damage path likewise narrowed to less than $100 \mathrm{~m}$. The shrinking stage lasted from 1318 


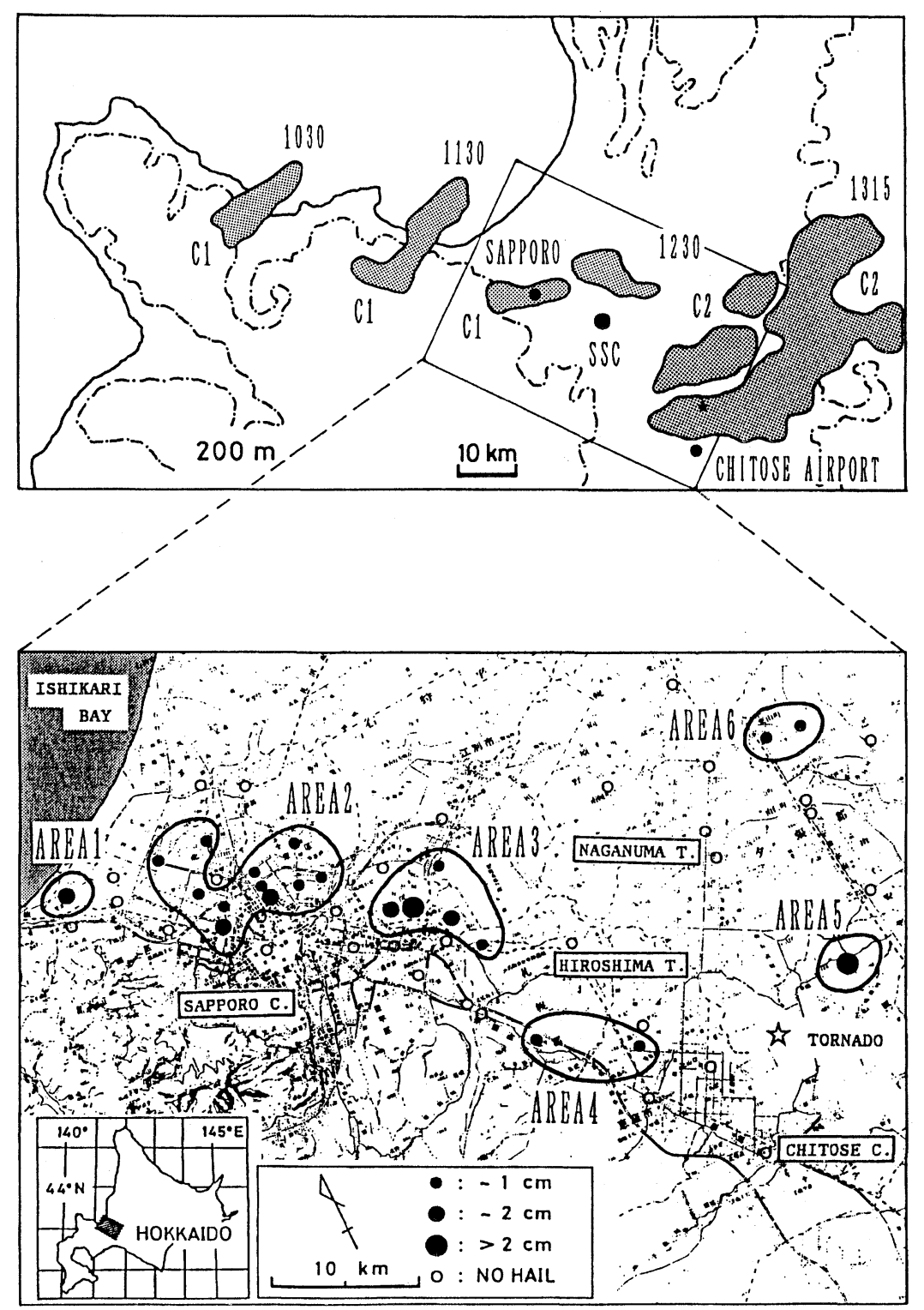

Fig. 12. Radar echo sketches at Sapporo Science Center (SSC) from 1030 JST to 1315 JST (top) and locations of hailstone precipitation reported (bottom). Star marks denote the location of the tornado. The beginnings of hailfall were 11:30 JST (Area 1), 11:30-12:10 (Area 2), 11:50-12:30 (Area 3), unknown (Area 4), 13:05 (Area 5) and 11:55-12:15 (Area 6).

to 1324 JST.

\subsection{Decaying stage}

After the tornado hit a farm house (Point $\mathrm{E}$ in Fig. 2) around 1324 JST, the funnel cloud began to retard from the ground (Fig. 3E, 4d). The parent cloud is found in the lower-left side of Fig. 3E and the rope-shaped funnel is seen aloft. Heavy rain started to the east side of the tornado (precipitating cloud is found in the center of Fig. 3E). The rainfall reached a house (Point E) just before the passage of the funnel cloud above the house, as shown in Fig. 4d. This indicates that cold air intruded to the location of the funnel near the ground. A gust of $15 \mathrm{~ms}^{-1}$ was recorded at 1340 JST at Chitose Air- port, which indicates the passage of a gust front (see Fig. 13). The rope-shaped funnel began to meander and slowly retard upward. It eventually disappeared after about five minutes.

\subsection{Evolution of the funnel and the dust cloud}

The evolution of the funnel size analyzed from the video image is shown in Fig. 9. Variations of the funnel width at two different altitudes, cloud base (1200 m AGL), half way (600 m AGL), the dust cloud width near surface (100 m AGL) and the surface damage width are shown in the figure. Remarkable changes in the funnel widths occurred when the funnel cloud reached the ground (1312 JST, the beginning of the mature stage): the funnel width had 

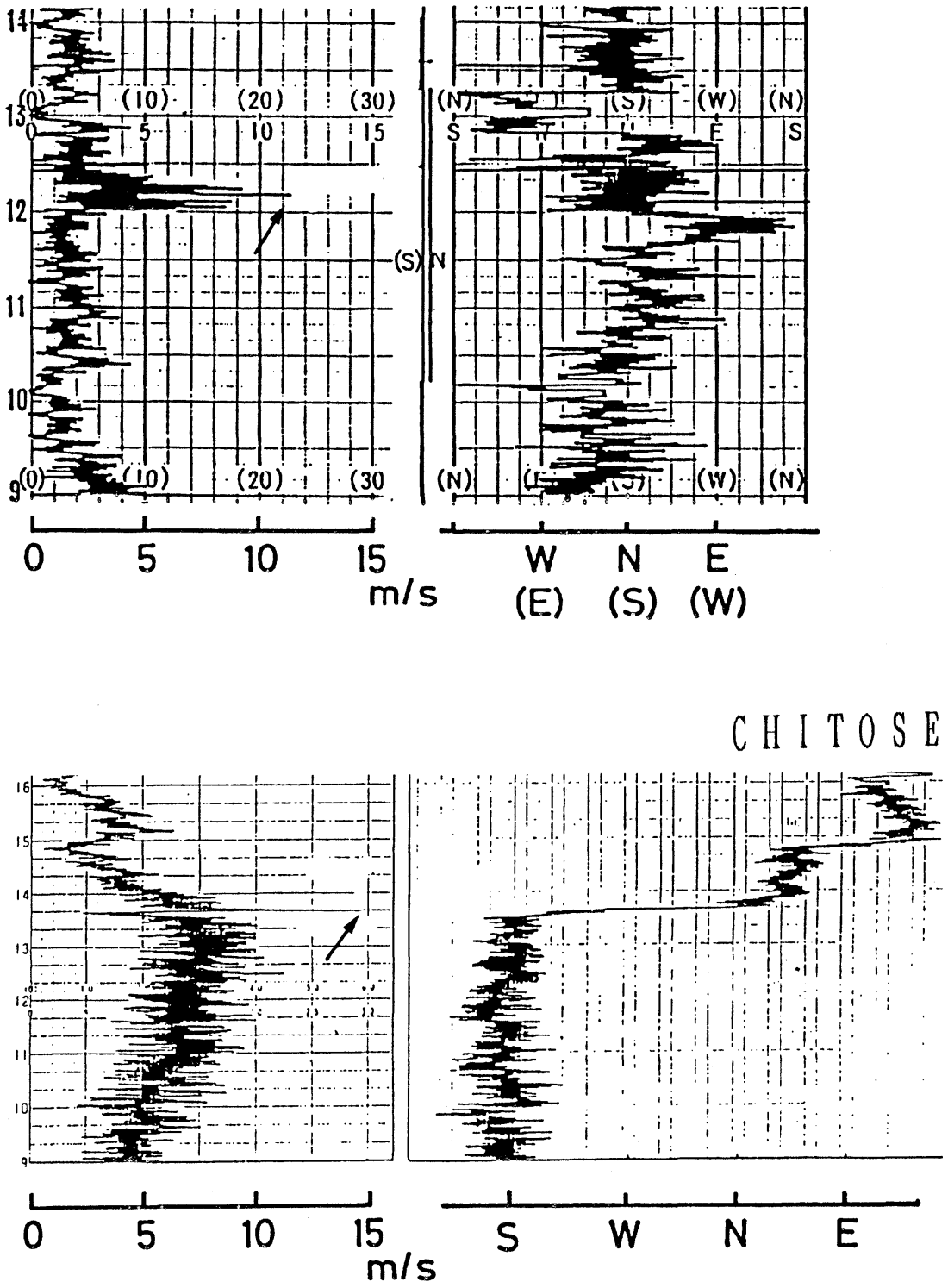

Fig. 13. Original records of wind at Sapporo (top) and Chitose Airport (bottom) on September 22, 1988.

decreased rapidly from $150 \mathrm{~m}$ to $60 \mathrm{~m}$ at the cloud base and from $60 \mathrm{~m}$ to $30 \mathrm{~m}$ half way up. The difference between the funnel width at the cloud base and at 600 AGL was quite large in the formation stage, but no difference was found in the shrinking stage. The dust cloud width, which reached $200 \mathrm{~m}$ at the mature stage, became narrow at 1318 JST (the beginning of the shrinking stage), as the funnel shape changed from straight to rope-like. The surface damage width almost coincided with the dust cloud width. The dust cloud disappeared in the shrinking stage before the funnel cloud did because of the difference of surface conditions and a beginning of surface rainfall.

The change of funnel width during the Chitose tornado life cycle was similar to those of some severe tornadoes in the United States as described by Golden and Purcell (1978), though the funnel scale of the former $(150 \mathrm{~m})$ was rather smaller than that of the latter. In the present case, the detailed structure of the tornado vortex i.e., the vortex tube, the funnel cloud, the dust column and the dust cloud, were revealed individually.

\section{Evolution and movement of tornadic storm}

\subsection{Doppler radar analysis of the parent cloud}

The Doppler radar observation of the Meteorological Laboratory, Hokkaido University was started at 1200 JST. The data of PPI displays at 10-minute in- 

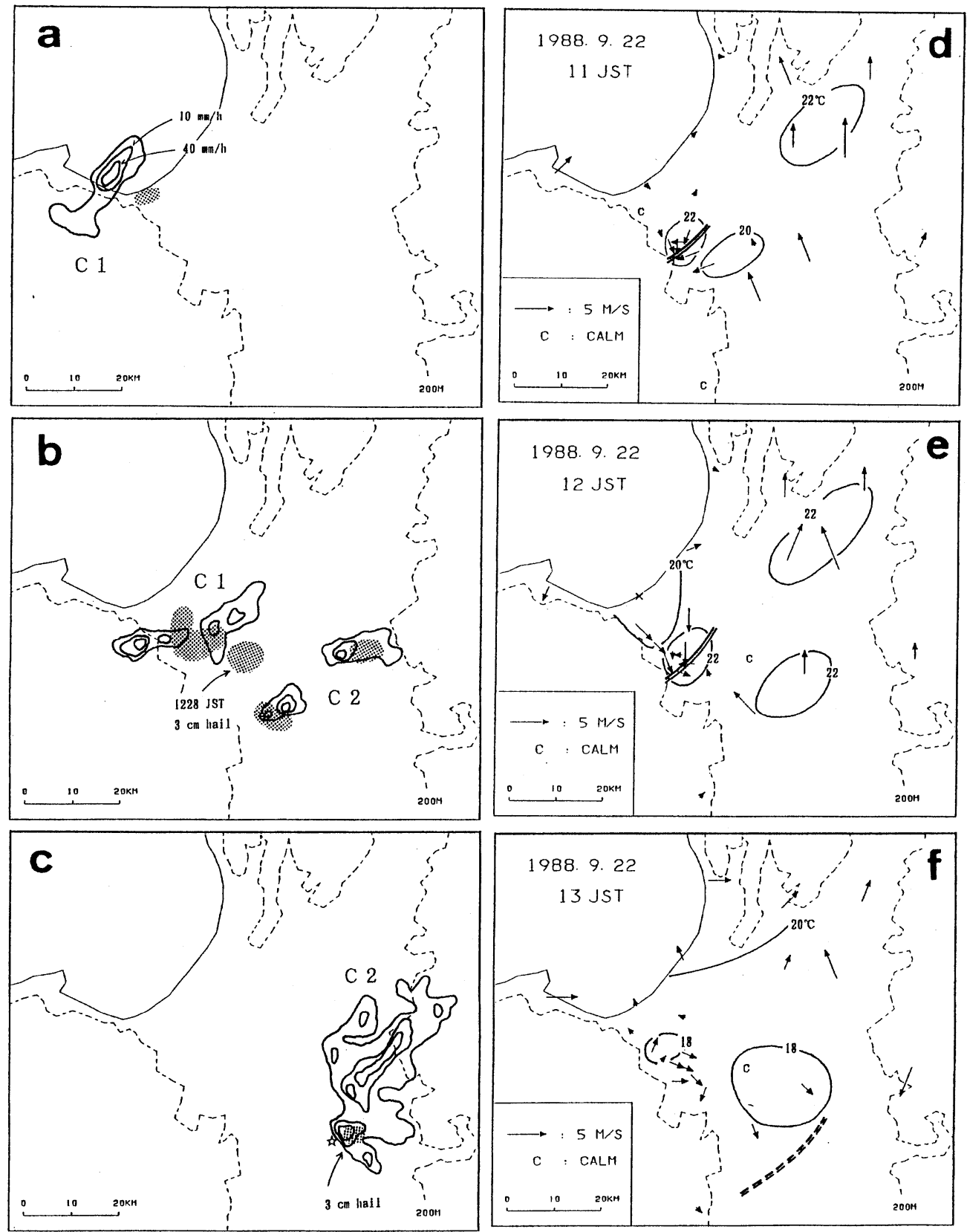

Fig. 14. Radar echoes recorded by the Sapporo Science Center and hailstone distributions (left side, $\mathrm{a}-\mathrm{c}$ ) and temperature and wind fields (right side, $\mathrm{d}-\mathrm{f}$ ). Double lines denote the convergence line.

tervals and from some RHI displays in the direction of the tornado were obtained. Figure 10 represents the PPI Doppler velocity at an elevation angle of $4.0^{\circ}$ at $1313 \mathrm{JST}$ (the time when the funnel cloud reached the ground). A distinct circulation (mesocyclone) in the parent cloud exists in a circle of $7 \mathrm{~km}$ in diameter. The maximum vorticity estimated from the Doppler velocity was of the order of $7 \times 10^{-3} \mathrm{~s}^{-1}$.

In the northwest quadrant of the mesocyclone, a couple of distinct peaks of positive and negative Doppler velocities exists in the region as indicated by a square. Figure 11 shows a close-up view of the region at $2.5 \mathrm{~km}$ AGL. The couple of the posi- tive and negative peaks in the Doppler velocity indicates the presence of a circulation the diameter of which was approximately $1 \mathrm{~km}$. The vorticity of this circulation (hereafter referred to as a misocyclone) was of the order of $6 \times 10^{-2} \mathrm{~s}^{-1}$. The tornado at the ground was located in the southwest quadrant of the misocyclone (Fig. 11). The location and the scale of the visible tornado vortex at the cloud base shown in Fig. 5 corresponds well to the circulation of the misocyclone shown in Fig. 11. Also, the relative positions of the tornado funnel as shown in Fig. $4 \mathrm{a}, 4 \mathrm{~b}$ and Fig. 5 coincided with the west side of the misocyclone analyzed by the radar. 


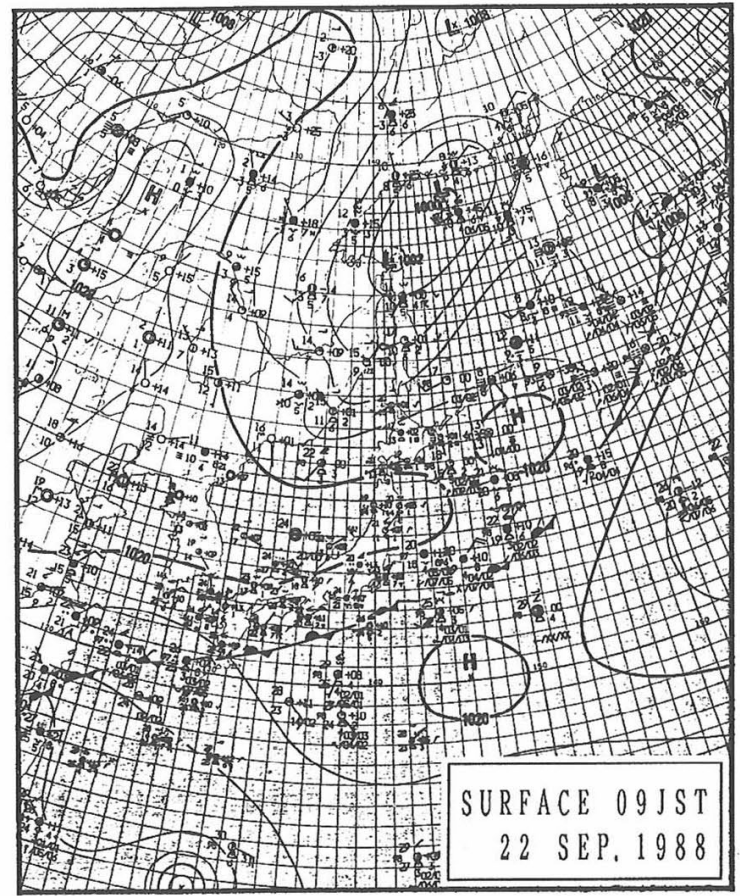

( a )

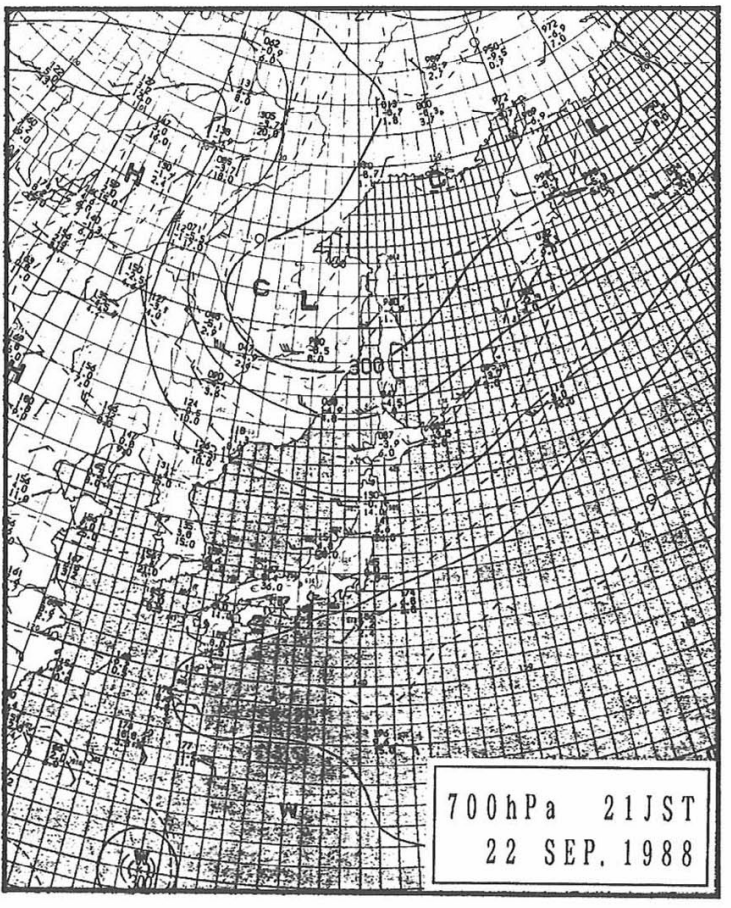

( b )

Fig. 15. Synoptic weather charts. (a) Surface at 09 JST September 22, 1988. (b) $700 \mathrm{hPa}$ at 21 JST.

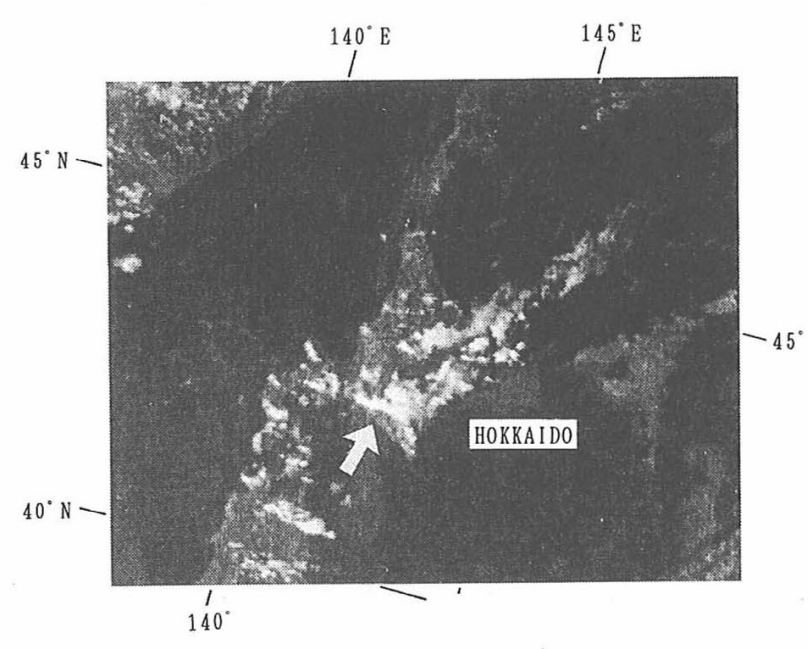

Fig. 16. NOAA visible image at 1515 JST, September 22, 1988. Wide arrow represents a convective cloud system with a severe thunderstorm.

The vorticity in the funnel was estimated from the wind speed obtained from video images (Fig. 8) and found to be $0.8 \mathrm{~s}^{-1}$ at $400 \mathrm{~m}$ AGL. The angular momentum per unit mass calculated for the funnel (400 $\mathrm{m} \mathrm{AGL)}$ and the misocyclone (2.5 km AGL) were 2025 and $1875 \mathrm{~m}^{2} \mathrm{~s}^{-1}$, respectively: i.e., the angular momentum of the tornado vortex at $400 \mathrm{~m}$ AGL is nearly equal to that of the misocyclone at $2.5 \mathrm{~km}$ AGL. In other words, the angular momen-

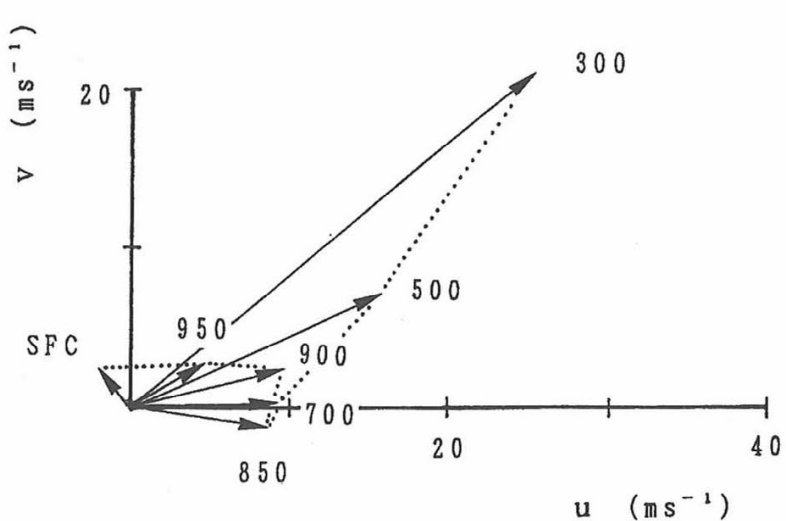

Fig. 17. Wind sounding hodograph of Sapporo at 09 JST September 22, 1988.

tum is conserved between the parent cloud vortex (misocyclone) and the tornado vortex.

\subsection{Movement of the tornadic storm}

The first radar echo (Cell C1) appeared at 1030 JST around the Shakotan Peninsula. Cell C1 advanced in an east-southeast direction at an average speed of $30 \mathrm{kmh}^{-1}$ (Fig. 12a). After $12 \mathrm{JST}$, a new echo (Cell C2) was generated about $30 \mathrm{~km}$ east of C1 and these two echoes merged at the east side of the Ishikari Plain. After merging, Echo C2 developed rapidly after 13 JST. This echo system was accompanied by large hailstones in several areas of 

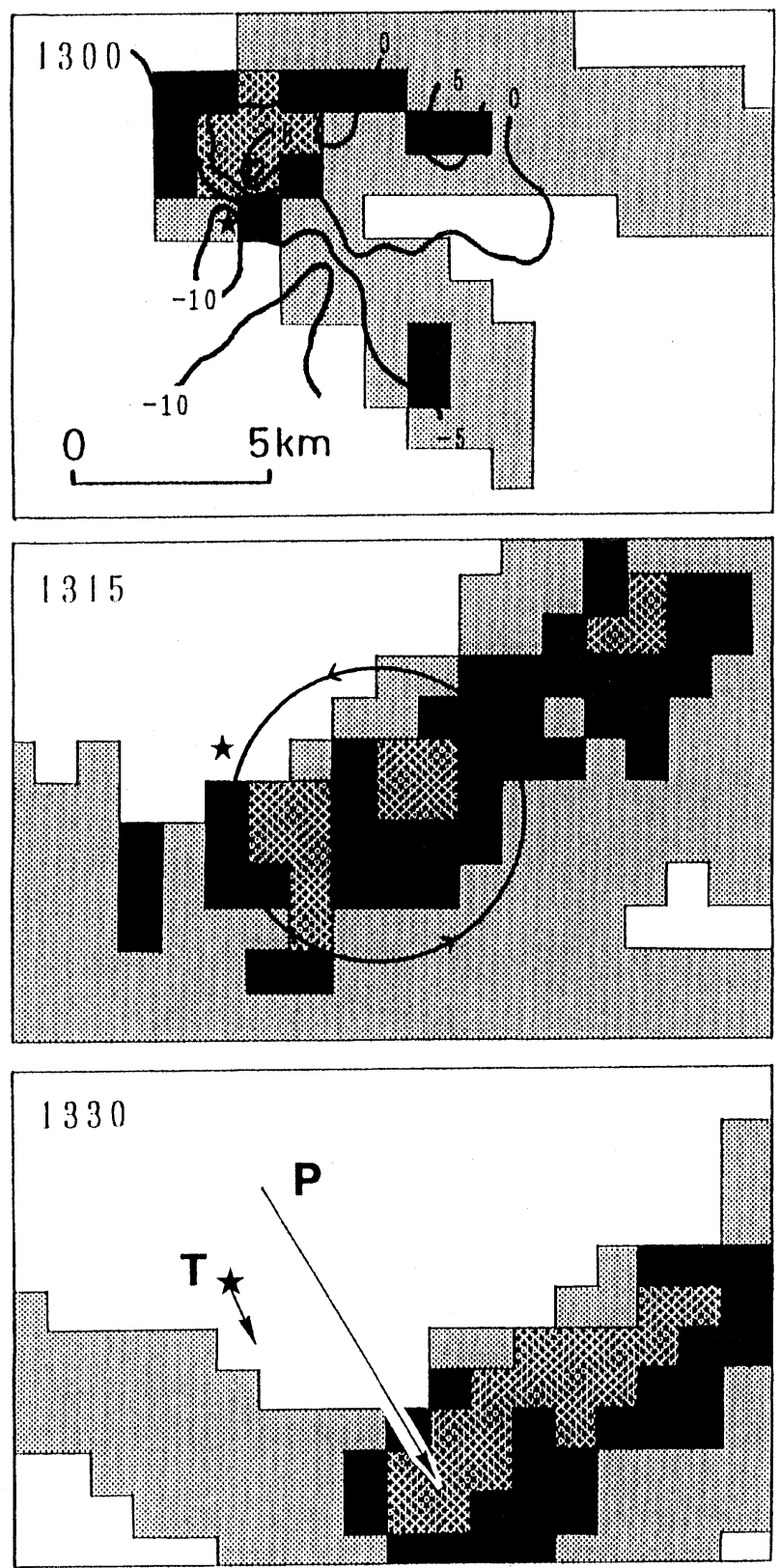

Fig. 18. Space relationship between the radar echo and the surface funnel. Echo intensity of $0.2,10,40 \mathrm{mmh}^{-1}$ is shown by shaded, solid and stippled area, respectively. Vectors $\mathrm{P}$ and $\mathrm{T}$ denote the movements of the parent cloud and the surface tornado. Star mark shows the location of funnel touchdown. Contours and a circle denote the Doppler velocity and the mesocyclone, respectively.

the Ishikari Plain. Figure 12b indicates each hailfall area reported from inhabitants and schools around the Ishikari Plain. The distributions of hailstones were divided into several closed areas and corresponded well with the development of echo cells in time: those in areas 1-3 are produced from Echo C1

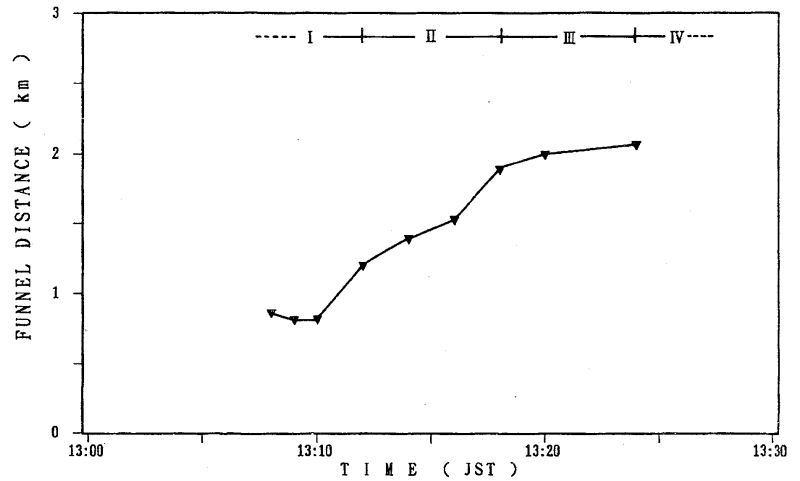

Fig. 19. Time change in funnel distance between the cloud base and surface. The east-west components are measured from Fig. 4.

and those in areas 4-6 are from Echo C2. In particular, hailstones larger than $3 \mathrm{~cm}$ in diameter were observed and collected on the east side of Sapporo City (Area 3, see Fig. 4, Kikuchi et al., 1989) and near the tornado (Area 5).

When the echoes passed over the Sapporo District Meteorological Observatory and the Chitose Airport Weather Station, a gust was recorded at each weather station. Wind direction changed from $\mathrm{W}$ to $\mathrm{N}$ before 12 JST at Sapporo and a gust of $11.3 \mathrm{~ms}^{-1}$ (1210 JST) was recorded (Fig. 13). A temperature drop of $4^{\circ} \mathrm{C} / 10 \mathrm{~min}$ was observed after $1200 \mathrm{JST}$ and strong precipitation of $20 \mathrm{mmh}^{-1}$ started after 1230 JST (not shown). These changes of the meteorological elements suggest the passage of a gust front associated with the echo system C1. In the same way, an abrupt change of wind direction from $\mathrm{S}$ to $\mathrm{N}$ and a gust of $14.8 \mathrm{~ms}^{-1}$ (1340 JST) were recorded at Chitose Airport.

In comparison with the locations of these echo areas and the temperature and wind fields in the Ishikari Plain, Echo C2 developed in the central part of the Ishikari Plain (Fig. 14a, 14b). The Echo C2 presented a hook echo pattern at the south edge of the system (Fig. 14c, close-up shown in Fig. 18). The generation areas of the echo cells corresponded to those of the relatively high-temperature zones $\left(22^{\circ} \mathrm{C}\right)$ which were about $2^{\circ} \mathrm{C}$ higher than the surrounding zones according to the mesoscale map using AMeDAS stations and weather stations supported by Sapporo City, as represented in Fig. 14d, 14e. Furthermore, the high-temperature zone near Sapporo corresponded to a wind-convergence zone (double solid line in the figure) between a northwesterly wind and strong southerly wind $\left(10 \mathrm{~ms}^{-1}\right.$, see Fig. 13) on the east side of the Ishikari Plain. The Chitose tornadic supercell storm developed rapidly in the central region of the Ishikari Plain where strong surface wind convergence occurred between a 


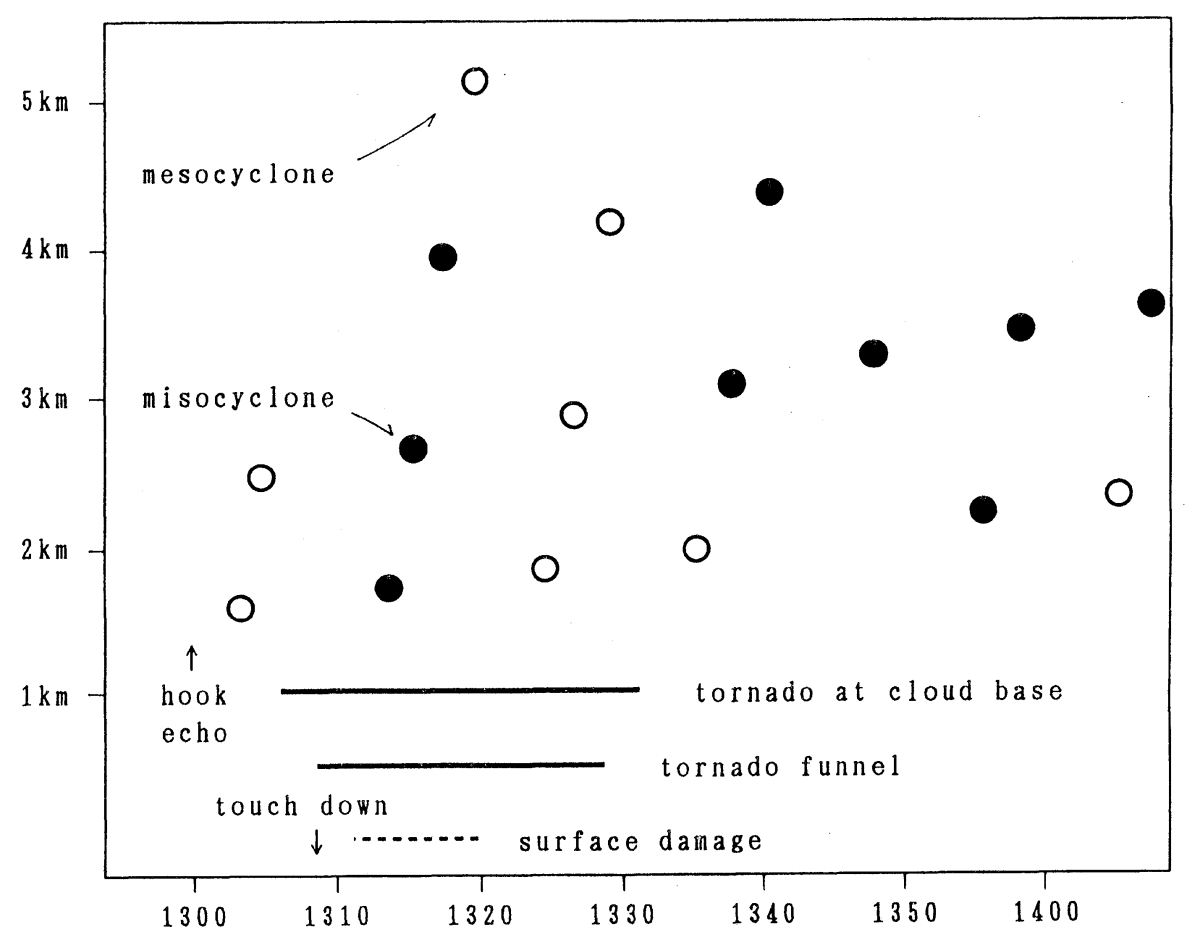

Fig. 20. Time history of the Chitose tornado activity. Open and solid circles show the existences of the mesocyclone $\left(10^{-3} \mathrm{~s}^{-1}\right)$ and the misocyclone $\left(10^{-2} \mathrm{~s}^{-1}\right)$ together with the mesocyclone, respectively. Solid and dashed lines denote life cycles of the tornado funnel and surface damage, respectively.

strong southerly wind and a northerly outflow from the echo (Echo C2).

Synoptic weather charts on September 22, 1988 (Fig. 15) indicate that there was a low-pressure center of $1000 \mathrm{hPa}$ over the northern Okhotsk Sea. There was a strong cold advection $\left(-9^{\circ} \mathrm{C}\right.$ at $700 \mathrm{hPa}$ level) from the Asian Continent with the advance of a trough, and an unstable condition prevailed throughout this period. This synoptic pattern is quite similar to the previous cases of severe storms around the Ishikari Plain e.g., a microburst event in Kita Village on September 23, 1986 (Kobayashi and Kikuchi, 1989) and a tornado event in Hiroshima Town on September 10, 1985 (Kobayashi et al., 1987). A satellite image at 1515 JST (Fig. 16) represents a broad cloud system which traveled from the east edge of the Ishikari Plain to the center of Hokkaido.

Thermodynamic quantities were computed based on the sounding of Sapporo at 0900 JST. The convective available potential temperature (CAPE) was $909\left(\mathrm{~m}^{2} \mathrm{~s}^{-2}\right)$ and the bulk Richardson number (Ri) was 58. Bluestein and Jain (1985) pointed out that high values of CAPE ( $>2000)$ accompanied by low values of $\mathrm{Ri}$ (15-35) favor the development of supercell thunderstorms. The wind hodograph (Fig. 17) exhibited a clockwise turning from surface (southeast) to $850 \mathrm{hPa}$ (west). A marked increase of vertical wind shear above $700 \mathrm{hPa}$ existed. Relative helicity $(\mathrm{H})$ is a normalized component of a storm-relative wind in the direction of the curl of the storm-relative wind field. Such a low value of $\mathrm{H}=0.05$ in this case, is not suitable for the development of a long-lived supercell storm (Bluestein and Jain, 1985). The thermodynamic environment of the Chitose tornado is not suitable for the development of a tornadic storm compared with that of supercell storms observed in the United States.

\section{Tornado funnel and parent cloud relation- ship}

The time and space relationship between the movement of the mesocyclone, the misocyclone and the funnel on the ground surface is discussed in this section. Figure 18 shows the spatial relationship between the tornado at the ground and radar echoes at 1300, 1315 and 1300 JST. The tornado was located near the strong echo area at the root of the hookshaped echo (1300 JST). Moreover, the location of the mesocyclone of $7 \mathrm{~km}$ in diameter observed by the Doppler radar coincided with the that of the hook echo. The mesocyclone moved south-southeastward in parallel with the movement of the surface tornado funnel. The former moved $6 \mathrm{~km}$ (Vector P) and the latter $1.5 \mathrm{~km}$ (Vector T) for 20 minutes. The differential speed of the parent cloud $\left(5 \mathrm{~ms}^{-1}\right)$ and the surface funnel $\left(1.2 \mathrm{~ms}^{-1}\right)$ may be due to the effect of the surface friction and the cold air barrier below the cloud base formed by a downdraft (see Fig. 4c, 4d). Although the funnel cloud at the surface 
Table 1. Characteristics of the Chitose tornado.

\begin{tabular}{|c|c|}
\hline \multicolumn{2}{|c|}{ TORNADO } \\
\hline life time & $20 \min$ \\
\hline funnel width & $150 \mathrm{~m}$ (cloud base) \\
\hline & $60 \mathrm{~m}(600 \mathrm{~m}$ AGL $)$ \\
\hline & $20 \mathrm{~m}$ (surface) \\
\hline dust cloud width & $200 \mathrm{~m}$ \\
\hline maximum wind speed & $\mathrm{V}=70 \mathrm{~m} / \mathrm{s}$ \\
\hline & $\mathrm{W}=85 \mathrm{~m} / \mathrm{s}(400 \mathrm{~m} \mathrm{AGL})$ \\
\hline vorticity & $0.8 \times 10^{0} \mathrm{~s}^{-1}$ \\
\hline swirl ratio & $\mathrm{S}=0.27$ \\
\hline \multicolumn{2}{|c|}{ DAMAGE } \\
\hline duration & $10 \mathrm{~min}$ \\
\hline tornado width & $20 \mathrm{~m}$ \\
\hline damage width & $200 \mathrm{~m}$ \\
\hline F scale & F1 \\
\hline $\mathrm{P}$ scale (length) & $\mathrm{P} 0(1.5 \mathrm{~km})$ \\
\hline P scale (width) & $\mathrm{P} 1(50 \mathrm{~m})$ \\
\hline \multicolumn{2}{|c|}{ PARENT CLOUD } \\
\hline life time & $50 \mathrm{~min}$ \\
\hline scale & \\
\hline mesocyclone & $7 \mathrm{~km}$ \\
\hline misocyclone & $1 \mathrm{~km}$ \\
\hline vorticity & \\
\hline mesocyclone & $7 \times 10^{-3} \mathrm{~s}^{-1}$ \\
\hline misocyclone & $6 \times 10^{-2} \mathrm{~s}^{-1}$ \\
\hline \multicolumn{2}{|c|}{ ENVIRONMENT } \\
\hline height of cloud base & $1.2 \mathrm{~km}$ \\
\hline CAPE & $909 \mathrm{~m}^{2} \mathrm{~s}^{-2}$ \\
\hline & 58 \\
\hline helicity $(\mathrm{H})$ & 0.05 \\
\hline
\end{tabular}

moved slowly, that at the cloud base moved eastward rapidly as shown in Figs. 3 and 4 . A "funnel distance" is defined as the horizontal distance between the funnel on the ground and that at cloud base. The variation of the funnel distance with time using video images which are east-west component frames, as shown in Fig. 4, is indicated in Fig. 19. The distance was $1 \mathrm{~km}$ at the formation stage, increased at the mature stage and reached $2 \mathrm{~km}$ after the shrinking stage due to the differential speed of the parent cloud and the surface funnel.

Figure 20 summarizes the time history of the Chitose tornado. The mesocyclone, which had a onehour lifetime together with the hook-shaped echo, first appeared about 10 minutes before the tornado touchdown. The parent vortex at the cloud base developed just after the appearance of the mesocyclone and lasted more than 20 minutes. The funnel formation (at the cloud base) occurred at the same time as the tornado vortex touchdown. The existence of the distinct misocyclone at mid-level $(2-3 \mathrm{~km}$ AGL, at 1310 JST) means that the tornado vortex developed immediately from the surface to the parent cloud, supported by a strong updraft. The tornado funnel and the dust column, which are visible parts of the tornado vortex, lasted for 20 minutes. The surface damage was produced during 10 minutes.

\section{Summary and concluding remarks}

On 22 September 1988, severe thunderstorms developed in the Ishikari Plain and spawned a tornado near Chitose Airport at around 1310 JST. The detailed structure of the single-funnel tornado and the relationship between the funnel and the parent cloud are revealed from photographs, videotape, ground survey, Doppler radar data, and surface and upper meteorological data. The characteristics of the Chitose tornado are summarized in Table 1.

The life cycle of the tornado is divided into four stages according to the time change of the funnel and width of the damage path. The first stage, characterized by the funnel formation, was followed by the mature stage in which the funnel cloud reached the ground and produced the strong dust cloud. The shrinking stage was characterized by a tilted and meandering funnel. The funnel retarded from the surface in the decaying stage because of an intrusion of a cold downdraft from a precipitating region. The diameter of the dust cloud nearly coincided with the surface damage width and was 10 times as large as 
that of the surface funnel width. The diameter of the misocyclone was about 10 times larger than that of the funnel at the cloud base.

In this case, the mesocyclone first appeared at mid-level (above $1.5 \mathrm{~km}$ ) and was accompanied with a hook-shaped echo which formed at the southwestern edge of the developing echo system. The mesocyclone had a diameter of $7 \mathrm{~km}$ and vorticity of $10^{-3} \mathrm{~s}^{-1}$. The misocyclone, having a diameter of $1 \mathrm{~km}$ and vorticity of $10^{-2} \mathrm{~s}^{-1}$, developed in the northwest region of the mesocyclone and coincided with the tornado vortex at the cloud base. The angular momentum of the misocyclone at $2.5 \mathrm{~km}$ AGL was equal to that of the funnel at $400 \mathrm{~m}$ AGL. The distance between the surface funnel and the parent cloud reached $5 \mathrm{~km}$ in the dissipating stage of the tornado, because of the differential speed between the parent cloud $\left(5 \mathrm{~ms}^{-1}\right)$ and the surface funnel $\left(1.2 \mathrm{~ms}^{-1}\right)$.

\section{Acknowledgments}

The authors are grateful to the Sapporo City Office, the Japan Meteorological Agency, junior and senior high schools, and primary schools around the Ishikari Plain for providing the meteorological data and the tornado and hailstone data. They wish to offer their thanks to Messrs. Y. Ino, Y. Takama and T. Koyama for providing photographs and a videotape.

\section{References}

Bluestein, H.B. and M.H. Jain, 1985: Formation of mesoscale lines of precipitation: severe squall lines in Oklahoma during the Spring. J. Atmos. Sci., 42, 1711-1732.
Fujita, T.T., 1973: Tornadoes around the world. Weatherwise, 26, 56-83.

Golden, J.H. and D. Purcell, 1978: Life cycle of the Union city, Oklahoma tornado and comparison with waterspouts. Mon. Wea. Rev., 106, 3-11.

Kikuchi, K., H. Uyeda, F. Kobayashi, K. Iwanami, R. Shirooka, N. Takahashi, K. Matsuura and N. Kanemura, 1989: On the hailstorm and tornado in Sapporo and its vicinity. Tenki, 36, 215-217 (in Japanese).

Kikuchi, K., H. Uyeda, F. Kobayashi and R. Shirooka, 1990: A microburst and gust front occurring near Sapporo (Chitose) Airport observed by a single Doppler radar. Proceedings Conference on Weather Radar and Flight Safety, Taipei. 51-57.

Kobayashi, F., K. Iwanami and K. Kikuchi, 1987: On the land spout occurred in Hiroshima-cho, Hokkaido, on Sept. 10, 1985. Geophys. Bull. Hokkaido Univ., 48, 17-33 (in Japanese with English abstract).

Kobayashi, F. and K. Kikuchi, 1989: A microburst phenomenon in Kita Village, Hokkaido on September 23, 1986. J. Meteor. Soc. Japan, 67, 925-936.

Kobayashi, F. and K. Kikuchi, 1994: Observational study of a tornado funnel and strong wind at the surface. Proceedings of 13 th National Symposium on Wind Engineering, Tokyo. 25-30.

Niino, H., O. Suzuki, H. Nirasawa, T. Fujitani, H. Ohno, I. Takayabu, N. Kinoshita and Y. Ogura, 1993: Tornadoes in Chiba prefecture on 11 December 1990. Mon. Wea. Rev., 121, 3001-3018.

Shirooka, R. and H. Uyeda, 1991: Doppler radar observation of tornado and microburst around Chitose Airport. Preprints, 25th Int. Conf. on Radar Meteorology, Paris, Amer. Meteor. Soc., J73-J76.

Wakimoto, R.M. and B.E. Martner, 1992: Observations of a Colorado tornado. part II: combined photogrammetric and Doppler radar analysis. Mon. Wea. Rev., 120, 522-543.

\title{
1988 年 9 月 22 日千歳竜巻のライフサイクル
}

\author{
小林文明 1 ・菊地勝弘・上田 博
}

(北海道大学理学部地球物理学教室)

1988 年 9 月 22 日 13 時すぎ石狩平野内で発達した severe stormに伴って千歳市内で発生した竜巻を、詳細 な現地調査、連続写真、ビデオテープやドップラーレーダー観測データから解析した。この千歳竜巻は 20 分間のライフタイム、漏斗雲(funnel)の直径 $150 \mathrm{~m}$ を有し F1 スケールの被害をもたらした。ライフサイク ルは漏斗の形状と被害特性の顕著な変化から、発生期、最盛期、衰弱期および消滅期の4つに分けられた。

\footnotetext{
${ }^{1}$ 現在所属: 防衛大学校地球科学科
} 
この竜巻の発生には直径 $7 \mathrm{~km}$ のメソサイクロン (mesocyclone) が高度 $2 \sim 3 \mathrm{~km}$ 程度で時間的に先行して 存在していた。雲底に扔ける漏斗雲の形状とメソサイクロンの北西象限で発生した直径 $1 \mathrm{~km}$ のマイソサイ クロン (misocyclone) とはほほ同時に観測され、発生場所も一致していた。地上の被害、漏斗雲掞よび親雲 の時間変化の特徵もまた明らかにされた。すなわち地上の被害幅 $(200 \mathrm{~m})$ は高度 $400 \mathrm{~m}$ まで舞い上がった “dust cloud(土埃)”のスケールと一致し、dust cloud および雲底の竜巻渦 $(1 \mathrm{~km})$ はそれぞれ地上と雲底に おける漏斗雲の直径のほほ 10 倍のスケールを有していた。竜巻の発生時点では、地上と雲底の竜巻渦の位 置はほぼ一致していたが、両者の移動速度の違いから時間とともに雲底下の漏斗雲および竜巻渦の挙動は かなり異なった様相を呈した。 